\title{
Discovery Learning Approach for Elementary School Student (A Case study in Elementary School PE Subject)
}

\author{
$1^{\text {st }}$ Maghfirotul Ulum \\ Physical Education, Health and \\ Recreation \\ State University of Malang \\ Malang, Indonesia \\ maghfipostman@gmail.com
}

\author{
$2^{\text {nd }} \mathrm{Mu}$ 'arifin \\ Physical Education, Health and \\ Recreation \\ State University of Malang \\ Malang, Indonesia \\ muarifin.fik@um.ac.id
}

\author{
$3^{\text {rd }}$ Febrita Paulina Heynoek \\ Physical Education, Health and \\ Recreation \\ State University of Malang \\ Malang, Indonesia \\ febrita.paulina.fik@um.ac.id
}

\begin{abstract}
This study aims to develop learning tools based on Discovery Learning model and test the feasibility of these development products in learning Physical education, Sports and Health on the small ball game material for high-grade students at the elementary school level. This study uses teh research and development method based on the model development by Borg $\&$ Gall. Based on the results of data analysis carried out, the product feasibilty level in the small group trial was $75 \%$ and the large group trial was $78 \%$. In the application of product development tools in the field, the highest syntax application activity is in the problem statement section with a percentage level of $33 \%$ in small group trials and $71 \%$ in large group trials. Based on these result, it can be concluding that the product development of learning tools based on the discovery learning model on small ball game material in elementary schools id suitable for use in the learning process at school.
\end{abstract}

Keywords - Discovery Learning, perangkat pembelajaran, permainan bola kecil.

\section{INTRODUCTION}

Education is one way that can be used to change the nature and degree of a human being. In order to educate the nation's life, education can function as a system to develop abilities, shape character and build dignified national civilization. Changes in the world of education at all levels will continue and cannot be avoided because it is in line with human culture itself which is dynamic and full of development. One of the efforts to support the improvement of superior and competitive human resources today is by means of education that is able to develop the potential of students, so that they can face and solve problems in the life they live in. The concept of this education will be felt when a person enters social life and is exposed to daily or future problems, so that the person concerned will apply what he has learned in educational institutions to solve these problems.

An efforts to create an ideal education system with today's society certainly require an approach and a way of working. There are various approaches and ways of working that can be used by educators to form a system, but in the context of education, learning strategies or methods are the dominant factors [1]. The selection of learning methods as an effort for educators to teach can be used as an indicator of improving the quality of students to achieve completeness or learning success. Although not the main factor, choosing a learning method that is not boring will make students more enthusiastic and motivated to develop their potential.

One of the applications of creative and innovative learning methods that can develop higher order thinking skills (Higher Order Thinking Skills) in the K-13 curriculum is discovery based learning. Discovery learning is a learning strategy that focuses on students to obtain information by means of scientific action, observation, or experiment [2].

Research conducted by [3] states that the Discovery Learning learning model which is designed to make active students work together in a group to form an idea based on a problem that has been solved by themselves is more effective in improving learning outcomes when compared to traditional methods such as one-way lectures. This is supported by research conducted by [4] on 61 students with an age range of 12-14 years, it was found that the types of sports activities programmed in an organized manner and carried out by students have a positive effect on behavioral development. prosocial learners. Pro-social behavior can be defined as behavior that shows a positive attitude towards others such as being willing to cooperate, considering the welfare of others, helping to help, and empathy. With proper guidance and direction from an educator, good and useful information will last longer in their memory.

Various activities carried out by students when getting the Discovery Learning learning method are considered to further increase their creativity at the stage of trying to solve a real problem. The theory above is concluded from research conducted by the research team [5] which concludes that the motor activity of students who develop in elementary school will certainly result in optimal physical growth. As a result of changes in their physical and cognitive structures, students at the elementary school level try to look mature. They begin to have confidence to prove that they are "grown up" so that they are ready to be given a task. This stage also includes the growth 
of independent action, collaboration with groups and acting in ways that are environmentally acceptable.

So, the student-centered learning process will shift the role of the teacher (teacher) to change as a facilitator. The results of research conducted by [6] on educators who teach using the Discovery Learning method show that this method provides a significant increase in the effectiveness of teaching and learning activities. Based on this study also, educators who were grouped by gender or gender who used this method found no significant differences. So it can be concluded that this teaching method is not problematic for use by all genders.

With a high coverage of learning objectives, a learning device is needed to help the teacher as a guide to help make it a success. Because based on research conducted by [7] states that teachers play an important role in helping the process of developing the skills of XXI century students based on the methods they choose to achieve these goals.

In order to support the level of professionalism in work, in fact there have been various studies that have been conducted to help educators with senior status and fresh graduation status to stick to their learning tools despite various conflicts. One of the research conducted by [8] entitled "Developing Professional Development Models for Physical Education, Sports, and Health Primary School Teachers in Learning Organizing" produces products in the form of printed documents, namely: (1) Module ; (2) Administration Guidelines; and (3) M\&E Guidelines.

However, the facts found in the field turn out that in the learning process there are still educators who do not have the learning tools they use as a guide or reference for these activities. This is based on a preliminary study conducted by researchers on PJOK Public Elementary School teachers in Nganjuk Regency who are accredited A, Public Elementary Schools accredited B and on private elementary schools in Nganjuk Regency which have been accredited A. Various reasons are the teacher's background for not making the learning tools, especially the lesson plans which are the basis for teaching action. In addition, the lesson plan can also be used as an indicator for the implementation of the teacher's activities because in the lesson plan there are learning steps that reflect the learning objectives, the Competency Achievement Index (GPA), learning methods and approaches, and learning models.

In fact, when referring to other research actions conducted by [9] which states that educators must prepare creative and innovative learning strategies by utilizing modern technology so as to increase student participation in learning, a learning device template is needed. which educators can use to maintain their standards of professionalism. In order to maintain the level of professionalism of PJOK teachers so that the standard of educators is not less competitive with educators of other subjects by providing learning device products with the Discovery Learning model template. This model template was chosen by researchers because it adapts to the latest curriculum used in Indonesia to form a generation who has higher thinking skills.

\section{METHOD}

Pengumpulan data dalam penelitian ini menggunakan Focus Group Discussion (FGD) untuk mendapatkan data kualitatif dari para ahli dan instrumen angket guna mendapatkan data kuantitatif dari subjek penelitian diuji coba kelompok kecil dan besar. Teknik analisis data yang digunakan dalam penelitian ini menggunakan teknik analisis kualitatif dan deskriptif kuantitatif. Teknik Pengukurn yang digunakan pada pengumpulan data berupa angket menggunakan skala linkert. Skala penilaian untuk skala linkert akan dipaparkan pada tabel 1. The type of research used here is development research or research with a Research and Development (R\&D) model. The method in this study uses a model developed by Borg \& Gall. The ten steps that have been proposed by Borg \& Gall will not be fully used in this study, because they adjust to the characteristics to be studied. So that in practice, 7 steps are used in accordance with the research.

The research and data collection stages were carried out as a needs analysis carried out in several elementary schools in Nganjuk Regency. The planning stage is the stage where the researcher makes an initial product design in the form of a learning device prototype containing a Learning Implementation Plan (RPP), teaching materials, and Monitoring and Evaluation (MONEV) guidelines. The next stage is the initial product development in which the product prototype is assessed for its validity by competent experts in their field before the product can be tested on research subjects. Product validation measures based on expert evaluation were carried out by 4 experts, namely: (1) 1) Dr. Pramono, S.Pd., M.Or., as an expert in learning Physical Education, Sports and Health, (2) Dr. Wasis D. Dwiyogo, M.Pd., as a curriculum expert, (3) Iwan Adi Pratama, M.Pd., and (4) Juwita Emlina Putri, S.Pd., as a national instructor expert for the Character Education Profession (Elementary School's Teacher) .

The trial phase is divided into 2 parts, namely small group trials and large group trials. Where this stage aims to measure the stages and assessments of users of the learning product. The product revision stage is an action where researchers improve the product based on suggestions and input from experts and users after trying to use the product. Revision action is carried out in the session after validation by experts and small group trials, so that the product used has a better level. The final stage is the product refinement stage where deficiencies in the product will be refined so that it becomes a product that is suitable for use by users.

The subject of the trial for expert learning in this development research is a lecturer at the Faculty of Education, State University of Malang, who has a minimum qualification of a master's degree in education and has an understanding in the field of physical education, sports and health learning. The subject of the trial for curriculum experts in this development research is a lecturer at the Faculty of Sport Sciences, State University of Malang, who has a minimum qualification of a master's degree in education and has an understanding of the curriculum. The test subjects of KDP national instructor experts in this study were certified and tested SD PJOK educators (UKG) who had the highest scores in their respective zoning so that they became core teachers. These teachers are assigned to 
train elementary school teachers in their respective regional zones due to curriculum changes, development and others. The subjects of the trials conducted in this study were certified physical, sports and health education teachers at the Nganjuk Regency Elementary School.

The types of data used in this development research are quantitative and qualitative. Qualitative data will be obtained after researchers conduct interviews and observations for needs analysis, evaluation from experts when assessing product prototypes. The form of qualitative data is in the form of sentences from the results of assessments, interviews, and observations. Quantitative data will be obtained during small group trials and large group trials using a questionnaire generated from filling in the research subjects.

Collecting data in this study using a Focus Group Discussion (FGD) to obtain qualitative data from experts and a questionnaire instrument in order to obtain quantitative data from research subjects tested in small and large groups. The data analysis technique used in this research is qualitative analysis and quantitative descriptive techniques. The measurement technique used in data collection was a questionnaire using a linkert scale. The rating scale for the linkert scale will be presented in table 1 .

Table 1. Rating Score for Positive Questions

\begin{tabular}{cccc}
\hline No & Description & Category & Score \\
\hline 1. & Strongly & A & 4 \\
2. & Agree & B & 3 \\
3. & Doubt & C & 2 \\
4. & Disagree & D & 1 \\
\hline
\end{tabular}

[10]

The formula used to process percentage data into descriptive uses the formula from [11]:

$$
P=\frac{f}{N} x 100 \%
$$

Information:

$$
\begin{aligned}
& \mathrm{P} \quad: \text { Percentage Number } \\
& \mathrm{f} \quad: \text { The Frequency that is being searched for } \\
& \text { the percentage } \\
& \mathrm{N} \quad: \text { The numbers of frequencies } \\
& 100 \% \quad: \text { Constants }
\end{aligned}
$$

\begin{tabular}{|c|c|c|}
\hline Percentage & Decription & Meaning \\
\hline $75,01 \%-100 \%$ & Very Valid & Can be Used Without Revision \\
\hline $50,01 \%-75,00 \%$ & Quite Valid & Can Be Used With Minor \\
\hline & & Revisions \\
\hline $25,01-50,00 \%$ & Invalid & Not Suitable for use \\
\hline $0 \%-25,00 \%$ & Very invalid & Forbidden to be used \\
\hline
\end{tabular}

Tobe able to determine the conclusions that have been reached, it is necessary to set the following criteria in table 2 .
Table 2. Product Quality Criteria

Source, [12]

\section{RESULT}

\section{A. The Expert}

The data obtained were in the form of assessments and suggestions for development products from 4 experts, namely: (1) one curriculum expert; (2) one expert in learning physical education, sports and health; and (3) two KDP national instructor experts (SD Teachers). The product development research will be described in table 3 .

Table 3. Data on the results of experts through Focus Group Discussion (FGD)

\begin{tabular}{llll}
\hline No. & Expert & Assessment, Criticism and Suggestions \\
& & \\
\hline 1. & Curriculum & 1. & Efforts to strive for learning resources based on
\end{tabular}

1. Curriculum
Expert 1. $\begin{aligned} & \text { Efforts to strive for learning resources based on } \\ & \text { electronic media such as videos, power points, e- }\end{aligned}$ books, and others.

2. The selection of learning methods is adjusted to the formulation of learning objectives.

3. Learning to take advantage of existing technology.

4. The RPP template that is finished is pursued in the form of an application so that it can be downloaded by other parties and campaign for paper-less learning.

2. 1 . The formulation of learning objectives and Physical competency achievement indicators (GPA) is in Education, accordance with the Bloom classification $(\mathrm{C} 1$ Sports and C6).

2. The part of the learning steps in the lesson plan so that $5 \mathrm{M}$ appears.

3. Revised skills competency assessment instruments to make it clearer and easier to understand.

4. The criteria for the attitude competency assessment instrument were changed in line with the skills competency assessment instrument.

5. Providing pictures as examples of formations or forms of

3. KDP National 1. Core Competencies and Basic Competencies are adjusted to the Permendikbud.

Expert

Instructor (SD 2. Come up with Competency Achievement Teacher) Indicators (GPA) in the RPP

3. Include the learning resources referred to in filling out the teaching materials in the lesson 
plans.Step 5 at sintkax put on main lesson plan.

4. Improvements in the sentence "affective, cognitive, and psychomotor" assessors become "attitudes, knowledge, and skills".

\section{B. Small Group Trial}

Based on the small group trial data, data analysis was obtained from each aspect which will be described in table 4 .

Table 4. Results of Small Group Trials Data Analysis for PE Teachers $(n=6)$

\begin{tabular}{lccl}
\hline No & Aspect & Eligibility & Category \\
\hline $\mathbf{1 .}$ & Easy & $75 \%$ & Very Valid \\
$\mathbf{2 .}$ & Fitness & $75 \%$ & Very Valid \\
\hline 3. & Entertaiment & $79 \%$ & Very Valid \\
\hline 4. & Uses & $71 \%$ & Quite Valid \\
\hline & Average & $\mathbf{7 5 \%}$ & Very Valid \\
\hline
\end{tabular}

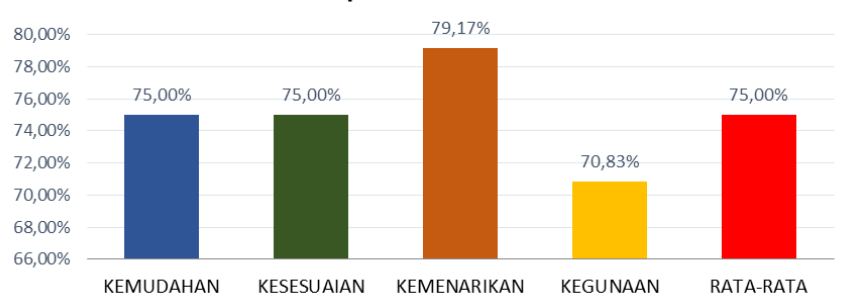

Figure 1. Percentage Diagram of Small Group Trial of PE Teachers in Primary Schools in Nganjuk Regency

Based on the small group trial data analysis table above, it can be concluded that with the percentage of the feasibility level, an overall average score of $75 \%$ is obtained, then converted to the eligibility qualification table, which shows a very valid category so that the product development of Discovery Learning based learning tools on small ball game The Nganjuk District Primary School can be used without revision for large group trials.

\section{Large Group Trials}

Based on the small group trial data, data analysis was obtained from each aspect which will be described in table 5 .

Table 5. Results of Large Group Trials Data Analysis for PJOK Teachers $(n=14)$

\begin{tabular}{cccc}
\hline No & Aspect & Eligibility & Category \\
\hline $\mathbf{1 .}$ & Easy & $78 \%$ & Very Valid \\
$\mathbf{2 .}$ & Fitness & $76 \%$ & Very Valid \\
\hline $\mathbf{3 .}$ & Entertaiment & $82 \%$ & Very Valid \\
\hline $\mathbf{4 .}$ & Uses & $77 \%$ & Very Valid \\
\hline & Average & $\mathbf{7 8 \%}$ & Very Valid \\
\hline
\end{tabular}

\section{Data on Large Group Trials Results for PE's Teachers}

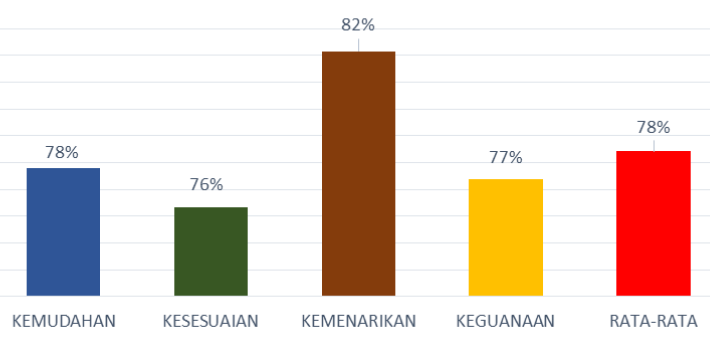

Figure 2. Percentage Diagram of Large Group Trial of PE Teachers in Primary Schools in Nganjuk Regency

Based on the data analysis table for large group trials above, it can be concluded that with the percentage of the feasibility level, an overall average score of $78 \%$ is obtained, then converted to the eligibility qualification table, which shows a very valid category so that the product development of Discovery Learning based learning tools on small ball game The Nganjuk District Primary School can be used without revision.

\section{Syntax Implementation Difficulty Data}

Data analysis was carried out based on the results of small and large group trials on a total of 20 PE's teachers, the data will be described in Figures 3 and 4.

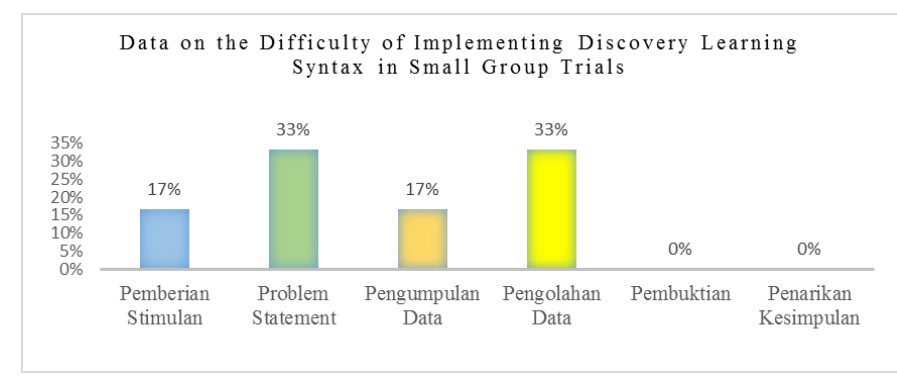

Figure 3. Percentage diagram of the difficulty in implementing Discovery Learning syntax in a small group trial

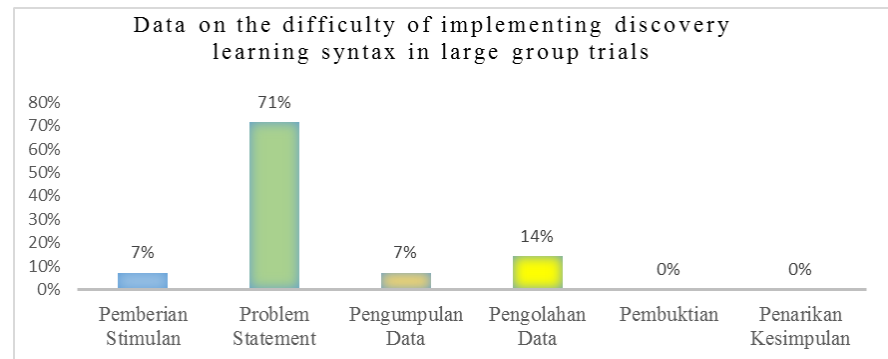

Figure 4. Percentage diagram of the difficulty in implementing Discovery Learning syntax in a large group trial 
Not all teachers are able to carry out activities according to the syntax stated in the RPP template due to various things such as facilities and infrastructure owned by the school, limited time for teaching, the number / input of different students, and others. These constraints are usually overcome by not bringing up syntax during teaching and learning activities or changing the form of activities so that the syntax continues. Based on the data above, it can be concluded that the teacher experiencing the highest difficulty is the problem statement syntax with a percentage of $33 \%$ in small group trials and $71 \%$ in large group trials. Another difficulty arises in the syntax of data processing by students with a percentage of $33 \%$ in small group trials and $14 \%$ in large group trials.

\section{DISCUSSION}

The product developed in this study is a learning device based on the Discovery Learning model on small ball game material. The learning tools are in the form of a Learning Implementation Plan (RPP), teaching materials and monitoring and evaluation (monev) guidelines. RPP developed in accordance with the format listed in Permendikbud No. 22 of 2016. RPP takes small ball game material that is adjusted to Core Competencies (KI) and Basic Competencies (KD) in high classes listed in Permendikbud No.37 of 2018.

The preparation of the RPP framework has also been carried out based on general criteria commonly used in educational institutions in Indonesia. This is in line with the research conducted by [13] which explains that the process of preparing lesson plans does not only include general steps such as providing equipment and preparation before teaching, but also includes the identity of the lesson plans, learning objectives, learning materials, learning methods., the steps of learning activities, learning resources and assessments. Every aspect has a realm that can be developed as needed, but basically all of them are one inseparable unit.

In this development, lesson plans are based on the learning model recommended by the 2013 Curriculum (K-13), namely the Discovery Learning model. The location of the most significant difference and differentiating it from other lesson plans lies in the part of the learning activity steps. There are 6 syntax used as learning activities. This statement is in accordance with the theoretical study of [14] which states that the syntax in the Guided Discovery Learning model is translated into Stimulation, Problem Statement, Data Collection, Data Processing, Verification. ), and Generalization (Withdrawing Conclusions).

Like the fact that occurs in the world that every plan must have obstacles that must be faced by the actors, the learning plans designed by each educator are also inseparable from this matter. In research by [15], it was found that the process in core activities got the lowest percentage of the level of conformity of learning activities with Learning Design (RPP). When compared with the initial activities (79.8\%) and closing activities $(68.8 \%)$, the core activities only got a percentage of $63.8 \%$.
Comparing the above theory with the RPP design made by the researcher, the syntax appearance is placed in the steps section in the core activity category. The test results show the problem statement syntax gets the highest percentage for the difficulty of performing an action. Almost all research subjects in both small and large group trials find it difficult to describe and apply the problem statement syntax. The reason was expressed by most of the subjects it took a long time to wait for students to express problems. Thus, some research subjects chose to unilaterally (one way) determine the problem that must be solved by each group and some other subjects chose not to carry out the syntax. This makes sense if you look at Piaget's cognitive development stage theory which says that the development of elementary school children's thinking is still egocentric, namely thinking and acting with self-center and center, namely the child's inability to concentrate on something [16].

Teaching materials are learning tools that researchers develop. Teaching material is a learning tool that is included in this development research because its function is in line as a reference for achieving Competency Achievement Indicators (IPK) in Core Competencies (KI) and Basic Competencies (KD). The components in this teaching material are in accordance with the theory written by [17] that the components of teaching materials are chapter titles, learning objectives, content descriptions, sub-chapters, content descriptions, pictures or illustrations, list of tables, examples, summaries and student activities.

From the results of the questionnaire it was also concluded that the teaching materials developed had an attractive design and were in accordance with their function. One of the real functions of teaching materials as a medium is to make it easier for teachers to convey information and make it easier for students to get information. This is in accordance with the opinion expressed by [18] that teaching materials can be used as an instrument to improve the quality of learning if they can be used properly by teachers and students.

Another product is a monitoring and evaluation (monev) guide. The monev guide contains instruments used to see the implementation of learning. The monitoring and evaluation guide developed contained 3 instruments, namely the monitoring instrument for the Discovery Learning model of PE subjects, the implementation of the Discovery Learning model for PE subjects, and the evaluation of learning in the Discovery Learning model for PE subjects.

\section{CONCLUSION}

In general, this learning device product already has the latest learning model. This refers to the education system in Indonesia which currently uses the K-13 Curriculum to form the character of students with high thinking skills (Higher Order Thinking Skills). The learning device produced from this research is the Learning Implementation Plan (RPP) which is based on Permendikbud No. 22 of 2016, Teaching Materials based on Permendikbud No. 22 of 2016 to be used during learning activities, and the MONEV Guide which contains monitoring and evaluation instruments for the implementation of learning activities. 
Based on the results of the analysis and discussion, research and development of learning tools based on the Discovery Learning model on small ball game material at Nganjuk District Elementary Schools that have been carried out, it can be concluded that the product development of learning tools based on the Discovery Learning model on small ball game material in elementary schools Nganjuk Regency is suitable for use in the learning process at school. However, in its application, it is adjusted again to the situation and conditions of each school

\section{REFERENCES}

[1] M. T. Ilahi, Pembelajaran Discovery Strategy \& Mental Vocation Skill. Yogyakarta: Diva Press, 2012.

[2] Saifuddin, Pengelolaan Pembelajaran Teoritis dan Praktis. Yogyakarta: Deepublish, 2014.

[3] A. G. Balim, "The Effects of Disscovery Learning on Student's Success and Inquiry Learning Skills," Egit. Arastirmalari-Eurasian J. Educ. Res., vol. 0, no. 35, pp. 120, 2009.

[4] O. K. Floric and S. Ninkovic, "The Contribution of Sport to Prosocial Behavior in Youth," New Educ. Rev., vol. 32, no. 2, pp. 141-150, 2013.

[5] L. E. Robinson et al., "Motor Competence and Its Effect on Positive Developmental Trajectories of Health," Sport. Med, vol. 45, no. 9, pp. 1273-1284, 2015.

[6] J. C. Anyafulude, "Impact of Discovery-based Learning Method on Senior Secondary School Physics," J. Teach. Perspect., vol. 8, no. 3, pp. 1-9, 2014.

[7] H. A. Alismail and P. McGuire, " 21 st Century Standards and Curriculum: Current Research and Practice," J. Eduction Pract., vol. 6, no. 6, pp. 150-154, 2015.

[8] F. P. Heynoek, Mu'arifin, and A. Kurniawan, "Developing Proffesional Development Model for Physical Education,
Sports, and Health Primary School Teachers in Learning Organizing," J. Indones. Phys. Educ. Sport, vol. 4, no. 2, pp. 79-87, 2018.

[9] C. B. Malsbary, "Teachersas Creative Designer in Transnationalism," Urban Educ., vol. 1, no. 27, pp. 1-27, 2015.

[10] Sugiyono, Metode Penelitian Pendidikan Pendekatan Kuantitatif, Kualitatif dan R\&D. Bandung: Alfabeta, 2015.

[11] A. Sudijono, Statistika Pendidikan. Jakarta: PT. Raja Grafindo Persada, 2008.

[12] Akbar and Sriwiyana, Pengembangan Kurikulum dan Pembelajaran. Malang: Cipta Media, 2011.

[13] M. Muspawi, "Profesionalitas Guru dalam Menyusun Rencana Pelaksanaan Pembelajaran (RPP) pada Sekolah Dasar Negeri No. 76/IX Desa Mandalo Barat Kecamatan Jakulo Kabupaten Muaro Jambi," J. Penelit. Univ. Jambi Seri Humanoria, vol. 17, no. 1, pp. 57-62, 2014.

[14] I. G. A. P. A. Wulandari, C. Sa'dijah, A. R. As'ari, and S. Rahardjo, "Modified Guided Discovery Learning: A Conceptual Framework for Designing Learning Model Using Guided Discovery to Promote Student's Analytical Thinking Skills," J. Phys. Conf. Ser., vol. 1028, no. 0, pp. 19, 2018.

[15] P. Anggraeni and A. Akbar, "Kesesuaian Rencana Pelaksanaan Pembelajaran dan Proses Pembelajaran," $J$. Pesona Dasar, vol. 6, no. 2, pp. 55-65, 2018.

[16] Al-Tabany, Mendesain Model Pembelajaran Inovatif, Progesif dan Kontekstual. Jakarta: Prenadamedia Group, 2014.

[17] F. P. Heynoek, Mu'arifin, Widijoto, Winarno, F. Amiq, and E. Hidayat, Pendidikan Jasmani dan Kesehatan Panduan bagi Mahasiswa Pendidikan Profesi Guru (PPG). Malang: LP3 UM, 2010.

[18] I. M. Sadjati, Pengembangan Bahan Ajar. Jakarta: Universitas Terbuka, 2012. 